\title{
The Flood Disaster Preparedness for Lembak Ethnic Children in Bengkulu City Watershed
}

\author{
Dalifa, Neza Agusdianita*, V. Karjiyati, Wurjinem and Inzoni \\ Primary Teacher Education Study Program, University of Bengkulu, Indonesia \\ ${ }^{*}$ Corresponding author. Email: nezaagusdianita@unib.ac.id
}

\begin{abstract}
This study aimed to determine the attitude of flood disaster preparedness for children who were in the watershed of the city of Bengkulu. This study provided an understanding of the steps to be prepared for flood disasters that could be done by children through simulations and videos about flood disasters. This research method was descriptive qualitative. The research instrument used was the interview and questionnaire guidelines. The subjects of this study were school-age children who live in watersheds that are often flooded. The results showed that most of the children in the watershed displayed an attitude of preparedness before the flood, during the flood, and after the flood. In addition, there was an attitude of preparedness for floods for children in the watershed that was developing quite well.
\end{abstract}

Keywords: Child, Flood disaster, Preparedness, Lembak ethnic.

\section{INTRODUCTION}

Environmental damage is marked by global warming, various kinds of pollution, flood disaster, and landslides. The handling effort has been carried out through various aspects, but in reality, the conditions of the environmental are still very poor. One of the environmental problems that need attention is the pile of household waste everywhere. People think that waste is useless and cannot be reused. Many people also throw their household waste into the river directly. That causes the river to become dirty and polluted, thus triggering silting of the river and catastrophic flooding.

The flood disaster that has occurred recently is very worrying. The river is no longer able to accommodate the discharge of rain, so the water stagnated in the residents' houses. Usually, Flood only occurs at the Tanjung Agung, Rawa Makmur, and Tanjung Jaya regions. However, in April 2019, the flood has inundated the Semarang, Surabaya, Nakau, Kandang Limun, and the area around.

An incident that occurred in the Sungai Serut subdistrict with high rainfall resulted in DAS of the river was overflowing in 2019 and 120 units of the residents' houses were flooded [1]. The incident also caused many casualties, livestock, property, and others were ravaged. It was even reported that some elementary school-aged children died because they were carried away while playing in the floods.

One of the reasons for elementary school-aged children became victims of flooding was that disaster preparedness materials were not maximally implemented into the learning process. The teachers' low understanding of the disasters characteristics in their respective regions means that there was a lack of learning on disasters that could be presented in a contextual manner. As a result, these early childhood students did not have adequate knowledge about disasters and reacted appropriately to the situation [2].

The research findings of [3] showed that students' knowledge of the flood disasters was still lack and the attitudes shown by the students in reducing the flood risk were also quite low. A large number of casualties for children was due to their inability to protect themselves when a disaster occurred. The inability of children to protect themselves was due to the lack of knowledge and skills of children when facing disasters [4]. Based on the phenomenon that occurred during the flood disasters, the research about flooded and its impacts needs to be carried out in Bengkulu City, because floods were the highest-ranking natural disasters, which was occurred 16 times in 2015, 39 times in 2016, and 31 times in 2017 [5]. 
The researcher was interested in describing how the flood disaster preparedness attitude of children, especially for the elementary school-aged children based on their ethnicity. The ethnic of the people lived in the watershed namely Lembak, Serawai, and Rejang ethnics. By obtaining a description of the flood disaster preparedness attitude data for elementary school-aged children in the watershed, it was hoped that it could become the basis for further activities. Such as creation of a school curriculum for flood disaster preparedness. The schools based on disaster preparedness were very important in preparing for disasters that could occur at any time [6].

\section{RESEARCH METHODS}

This study used the desciptive qualitative approach. Qualitative descriptive research according to Best [7], as quoted by Sukardi, was a "research method that seeks to describe and interpret objects according to what they are". Likewise, Prasetya stated that "descriptive research is research that explains the facts as they are".

Qualitative research was research whose findings were obtained based on a qualitative paradigm, strategy, and implementation of the model. Meanwhile, according to Manca as quoted by Moleong, qualitative research has the following characteristics: (1) it was a German tradition based on idealism, humanism, and culturalism; (2) this study could produce theories, developed understanding, and explained complex realities; (3) characteristic of an inductive-descriptive approach; (4) it took a long time; (5) data in the form of descriptions, documents, field notes, photographs, and drawings; (6) the informant was "Maximum Variety"; (7) process-oriented; (8) the research has a micro context [8].

If the study was viewed by the point of view of the ability or the possibility that it could provide information or explanation, this was a descriptive study. A descriptive study was a study that attempted to describe certain social units which included individuals, groups, institutions, and society. In this case, the researcher seeks to describe in depth how the attitude of flood disaster preparedness for elementary school-aged children in the watershed in terms of ethnicity.

\section{RESULTS AND DISCUSSION}

\subsection{Results}

\subsubsection{Ethnic descriptions in the Watershed}

This study aimed to determine the flood disaster preparedness attitude of children living in the watershed of Bengkulu City. The watershed of Bangkahulu's river was an area that often stricken by flood disaster. The area of Muara Bangkahulu Subdistrict was in 3 flood- prone zones, namely one prone, two prone, and three prone with the most vulnerable areas at the Rawa Makmur, Rawa Makmur Permai, and Beringin Raya [9]. Some authors, [10] and [11], both provided information that the area of Tanjung Agung, Sungai Serut subdistrict was an area that always stricken by flood disaster every year.

Based on the data results of the study obtained, there were several ethnic groups living in the watershed (Figure 1). Among them were Lembak, Serawai, Rejang, Bengkulu, Java, Melayu, and Batak ethnic. Most ethnic groups were soft. The majority of the people in Sungai Serut Sub-district were Lembak ethnicity. The following showed the various ethnic distribution areas in the watershed of Bengkulu City.

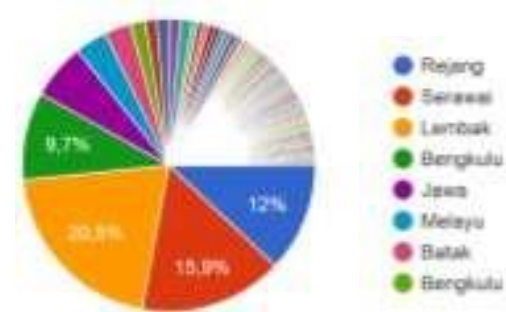

Figure 1. Ethnic Distribution in the Watershed of the Bengkulu City

\subsubsection{Description of Children Flood Disaster Preparedness Attitude from Lembak Ethnic}

The flood was a disaster that always occurred every year in the watershed of Bengkulu city. The majority of ethnic groups who lived in the area were Lembak ethnic. The first areas that became the targets of the flood disasters were Tanjung Agung and Rawa Makmur areas. Researchers had distributed questionnaires for the Elementary school-aged children of some public and private elementary schools around the watershed.

The attitude of flood disaster preparedness studied was divided into three aspects, namely the attitude of flood disaster preparedness before a flood occurred, when a flood occurred and after a flood occurred. Preflood preparedness attitudes included: 1) I had identified my living area as a flood-prone area, 2) I did not throw the household waste in drains or rivers, 3) Streams and drains in the area where I live were always cleaned, 4) I kept trees around my living area to protect water catchment areas and 5) When the rainy season started, I would secure of my important and valuable items.

The attitudes of flood disaster preparedness during a flood included: 1) When a flood occurred, I turned off the electricity at my home, 2) During a flood, I evacuated to a safe area, 3) During a flood, I helped people to set up a public post and kitchen, 4 ) During floods, I used the clean water that was provided to avoid disease and 5) When floods, I paid attention to signs of the flooding and monitor of the situation flood. 
The attitude of flood disaster preparedness after a flood included: 1) I helped clean of the houses and household appliances with disinfectants or anti-bacteria, 2) I helped my parents to clean of water sources or wells from rubbish carried by the floods, 3) Used of the clean water to avoid illness, 4) I was always alert to warnings of subsequent flood disasters, and 5) Beware with the remains of the wastes and animals that were carried away by the flood. The following was presented on the table below about the distribution of flood disaster preparedness with the highest and lowest scores.

Table 1. Distribution of Lembak Ethnic about Flood Disaster Preparedness Attitudes

\begin{tabular}{|c|c|c|}
\hline $\begin{array}{l}\text { Attitude } \text { Aspects } \\
\text { of the Flood } \\
\text { Disaster } \\
\text { Preparedness }\end{array}$ & $\begin{array}{l}\text { The highest } \\
\text { scores of the } \\
\text { attituded }\end{array}$ & $\begin{array}{l}\text { The lowest } \\
\text { scores of the } \\
\text { attitude }\end{array}$ \\
\hline $\begin{array}{l}\text { Before a flood } \\
\text { disaster occurred }\end{array}$ & $\begin{array}{l}\text { Didn't throw the } \\
\text { household waste } \\
\text { in drains } \\
\text { or rivers }\end{array}$ & $\begin{array}{l}\text { Identified the } \\
\text { living area as } \\
\text { a flood-prone } \\
\text { area }\end{array}$ \\
\hline & $\begin{array}{l}\text { Kept } \begin{array}{r}\text { trees } \\
\text { around }\end{array} \text { the } \\
\text { living area to } \\
\text { protect water } \\
\text { catchment } \\
\text { areas }\end{array}$ & \\
\hline $\begin{array}{l}\text { When a flood } \\
\text { disaster occurred }\end{array}$ & $\begin{array}{l}\text { Used the clean } \\
\text { water that was } \\
\text { provided to } \\
\text { avoid disease }\end{array}$ & $\begin{array}{l}\text { Helped the } \\
\text { people to set } \\
\text { up a public } \\
\text { post and } \\
\text { kitchen }\end{array}$ \\
\hline $\begin{array}{l}\text { After a flood } \\
\text { disaster occurred }\end{array}$ & $\begin{array}{l}\text { Helped the } \\
\text { parents to clean } \\
\text { of water } \\
\text { sources or wells } \\
\text { from rubbish } \\
\text { carried by the } \\
\text { floods }\end{array}$ & $\begin{array}{l}\text { After the } \\
\text { flood, used } \\
\text { the clean } \\
\text { water to avoid } \\
\text { disease }\end{array}$ \\
\hline
\end{tabular}

\subsection{Discussion}

The watershed of Bengkulu city was an area with the majority of Lembak ethnicity people. The most areas frequently hit by flood disasters were Tanjung Agung and Rawa Makmur areas. This area was regularly flooded every year. One of the causes of flooding was due to the high intensity of rain and also the activity in the upstream river that has become uncontrolled due to mining and plantation activities, resulting in flooding especially that occurred in the area around the Watershed of Bengkulu River [12]. However, all of the people there seem had been made friendly with the flood disaster. They seem to remain calm when it started to rain heavily and water started to inundate their house.
Researcher has analyzed several previous studies that reveal the reasons why the people did not want to move from these flood-prone areas. The reason that residents had lived for a long time from generation to generation; residents had anticipated flooding by elevating their houses, beside of that because their relatives also remain in the area. According to Angraini [13] people did not want to move and adapt because they were comfortable with the surrounding environment, close solidarity between others, and there was a hope that has given by the government to local communities to cope with flood disaster in this area.

The main reason of the people continued to live in the prone area to flooding every year was limited costs and also the difficulty to sell their houses because every people of Bengkulu city were known as flood-prone areas [14]. In addition, according to Santri [15] the reasons for the local communities to get on with life in the current location were the strategic locations, the relationship between residents was quite good, and the status of owning was their own house or family own house.

Thus, residents in flood-prone areas could be said to stay in the area even though they have to confront with floods disaster every year. For this reason, the government should increase the understanding and skills of the residents with flood disaster preparedness. Especially, for children who were still elementary school-aged. Children would always be victims when a flood occurred because children really like playing in puddles. The implementation of flood disaster preparedness activities could increase knowledge of flood disaster mitigation [16].

Therefore, the children would not return to being flood victims when the flood disaster occurred. The Governments should also have rules and standards for child friendly in place. A Child-Friendly District or City was a child rights-based development system through the integration of commitments and resources from the government, society, and the business, which was planned thoroughly and sustainably in the policies, programs, and activities to ensure the fulfillment of children's rights and protection [17].

In order to reduce the number of children who became victims during the flood disaster, the school could also take a part. Teachers could provide education to the students about flood disaster preparedness. [18] also emphasized that there was a relationship between the preparedness of teachers and parents about the potential for flood disasters. Education on the TAGANA Concept (Disaster Alert Response) for School-Aged Children provided an understanding of disasters and their mitigation, so that students increased their knowledge, both in theory and practice [19]. 
In addition, teachers could provide pocketbooks or manuals for flood disaster mitigation books for children aged 5 to 6 years. This could add to the knowledge and information of the teachers in conveying the flood disaster mitigation learning to students through structured and conceptual activities so as to improve the flood disaster preparedness of the children [20]. Cahyadi [21] also presented that material on flood disaster preparedness through comics. The benefits of disaster preparedness comics, participants assessed that comic illustrations were simple, interest, educational content and easy learning for the students to understand, it was able to foster students' reading interest, and raised the students' awareness of the importance of maintaining cleanliness.

Besides the schools, the government should also carry out various training and socialization activities on a regular basis for the people that lived in flood-prone areas. BNPB or BPBD had been a role directly to authorize in disaster management, especially in the flood disaster mitigation [22]. As a study conducted by Fahlevi [23], the Regional Disaster Management Agency (BNPB) team coordinated with the residents in Mugirejo Village to do several things to reduce the risk of floods including 1) made of evacuation shelter posts, 2) prepared of the buoys, and 3) logistics. Nadiya [24] also explained that the strategies used to build a flash floods preparedness community, namely forming groups or communities through planted a thousand trees, collected of the garbage as an effort to prepare for flood disasters and also reduced the risk of a flash flood disaster.

\section{CONCLUSION}

. In summary, an attitude of preparedness before the flood, during the flood, and after the flood was showed by most of the children living in the watershed. Furthermore, the development of children's attitude of preparedness for floods in the watershed was quite well. We hope that the results of this study will be of use to stakeholders in mitigating flood disaster in future.

\section{ACKNOWLEDGMENTS}

The author would like to thank the research institute and community service at the University of Bengkulu who has been supported the facilities and funding for this research.

\section{REFERENCES}

[1] Sari, Julia Purnama, Arie Vatresia, Ferzha Putra Utama. "Pemetaan Daerah Kawasan Banjir Kecamatan Sungai Serut Kota Bengkulu," Abdi
Reksa : Jurnal Ilmiah, Vol. I, No.1, pp. 13-18, 2020

[2] Tirtayani Luh Ayu, I Nyoman Jampel. Materi Siaga Bencana Pada Kurikulum Pendidikan Anak Usia Dini (PAUD) di Bali : Prosiding Seminar Nasional dan Call For Paper Peranan Psikologi Bencana Dalam Mengurangi Risiko Bencana, 2018

[3] Rosyida Fatiya dan Khofifatu Rohmah Adi2. "Studi Eksplorasi Pengetahuan Dan Sikap Terhadap Kesiapsiagaan Bencana Banjir Di Sd Pilanggede Kecamatan Balen Kabupaten Bojonegoro," Jurnal Teori dan Praksis Pembelajaran IPS. Vol.2 No.1, pp. 1-5, 2017.

[4] Elita Yessy, Rita Sinthia, Mona Ardina. Disaster Preparedness For Student Of Elementary School Through Educative Games "AKSANA". Dharma Raflesia Unib Tahun XVII, No. 1, Pp. 40-47, 2019.

[5] BPBD. Peta Kerawanan Banjir Kota Bengkulu Provinsi Bengkulu, BPBD Kota Bengkulu, Bengkulu, 2018.

[6] Karjiati, V, dkk. Pengembangan Model Pembelajaran Tematik Kesiapsiagaan Bencana Banjir Bagi Siswa Sekolah Dasar di Daerah Aliran Sungai (DAS) Kota Bengkulu. Laporan penelitian: UNIB, 2019

[7] Sukardi, Metode Penelitian Pendidikan: Kompetensi dan Prakteknya, Jakarta: Bumi Aksara pp. 157, 2005

[8] Moleong, Metodologi Penelitian Kualitatif, Bandung: PT Remaja Rosdakarya, 1999

[9] Suherianti, A. Mayub, M. Farid. "Potensi rawan banjir kecamatan muara bangkahulu sebagai penunjang pembelajaran materi pemanasan global di smpn 11 kota bengkulu. Pendipa," Journal of Science Education, Vol. 2, No. 1, Pp. 95-102, 2018

[10] Farid.M, Sunarto, Suryanto.W. Investigation Of Flood Potential Areas in Bengkulu City, in The 7th Annual Basic Science International Conference), pp. 7-8, 2017

[11] Himbawan, GIGIH. Penyebab Tetap Bermukimnya Masyarakat Di Kawasan Rawan Banjir Kelurahan Tanjung Agung Kota Bengkulu, semarang: Laporan Tesis, 2010

[12] Setiawan Yudi, Endina Putri Purwandari2, Andang Wijanarko3, Etis Sunandi4. "Pemetaan Zonasi Rawan Banjir Dengan Analisis Indeks Rawan Banjir Menggunakan Metode Fuzzy Simple Adaptive Weighting," Jurnal Pseudocode, Vol. 7, No. 1, pp. 78-87, 2020

[13] Angraini, Yelvika. “Adaptasi Masyarakat Kawasan Banjir Gang Rawa Bangun Kelurahan Bangkinang 
Kecamatan Bangkinang Kota Kabupaten Kampar," Culture \& society: journal of anthropological research. Vol, 1, no. 1, 2019

[14] Pratama M Randi. Adaptasi Masyarakat Perumahan Dinar Indah Kota Semarang Terhadap Bencana Banjir, semarang : Laporan Penelitian, 2019

[15] Santri, Enggar Apriyanto, Satria Putra Utama. "Dampak Sosial Ekonomi Dan Estimasi Kerugian Ekonomi Akibat Banjir Di Kelurahan Rawa Makmur Kota Bengkulu Naturalis," Jurnal Penelitian Pengelolaan Sumberdaya Alam dan Lingkungan, pp. 77-84, 2020

[16] Pratiwi Nur Hasna, Upik Elok Endang Rasmani, Nurul Shofiatin Zuhro. "Meningkatkan Pengetahuan Mitigasi Bencana Melalui Kegiatan Kesiapsiagaan Bencana Banjir Pada Anak Usia 5-6 Tahun," Jurnal Kumara Cendekia. Vol. 8, No. 3, pp. 280-290, 2020.

[17] Nurfadilah1, Deira Razzaaq Darsono. Peran Pengambil Kebijakan Dalam Memberikan Edukasi Tanggap Darurat Bencana Banjir Di Bendungan Hilir. Monograph (Discussion Paper). Tidak Diterbitkan, 2020.

[18] Aprilin Heti,Setya Haksama, Makhfludi. "Kesiapsiagaan sekolah terhadap potensi bencana banjir di SDN gebangmalang kecamatan mojoanyar kabupaten mojokerto," Jurnal Biosains Pascasarjana, Vol. 20, pp.133-145. 2018.

[19] Prima Keprila Fani, Yualitas Gusmareta, Rijal Abdullah, Fitra Rifwan Prima Zola. "Edukasi Konsep Tagana (Tanggap Siap Bencana) Untuk Anak Usia Sekolah Di Daerah Rawan Bencana Kabupaten Solok Selatan Sumatera Barat," CIVED: Journal of Civil Engineering and Vocational Education. Vol. 7, No. 2, pp. 58-62, 2020.
[20] Hanan Sely Anisah, Muhamammad Reza. "Pengembangan Buku Panduan Kegiatan Pembelajaran Mitigasi Untuk Meningkatkan Kesiapsiagaan Bencana Banjir Pada Anak Usia 5-6 Tahun," Jurnal PAUD Teratai, Vol. 9, No. 2, Pp. 115, 2020.

[21] Cahyadi Ani, Murniningsih, M. Irfan Islamy. "Pengembangan Komik Sains Untuk Siswa Sekolah Dasar/Madrasah Ibtidaiyah Menuju Banjarmasin Siaga Banjirmadrasah," Jurnal Pendidikan dan Pembelajaran Dasar, Vol. 9, No. 1, 2016.

[22] Suleman, Syahputra Adisanjaya, Nurliana Cipta Apsari. "Peran stakeholder dalam manajemen bencana banjir," Prosiding ks: riset \& pkm. Vol. 4, No. 1, pp. 1 - 140, 2017.

[23] Fahlevi Muhammad Reza. "Strategi Adaptasi Masyarakat Kelurahan Mugirejo Kota Samarinda Di Dalam Menghadapi Banjir," eJournal SosiatriSosiologi, vol. 7, no. 1, pp. 154-168, 2018.

[24] Nadiya ajeng. Membangun masyarakat siaga bencana banjir di desa perning kecamatan jatikalen kabupaten Nganjuk. Surabaya. Laporan penelitian mahasiswa unived, 2019. 